\title{
PERENCANAAN KEPERAWATAN BAGIAN DARI ASUHAN \\ KEPERAWATAN
}

Inayah Husna Sibarani / inayahhusna08@gmail.com

\begin{abstract}
ABSTRAK
Asuhan keperawatan adalah suatu pendekatan untuk pemecahan masalah pada pasien dengan memberikan pelayanan keperawatan. Sejauh ini perawat tidak sepenuhnya melakukan asuhan keperawatan sesuai dengan SOP. Proses keperawatan adalah salah satu metoda efektif pemecahan masalah yang dilakukan perawat terhadap klien dengan pendekatan metodologi ilmiah. Asuhan keperawatan dapat dipertanggungjawabkan berdasarkan substansi ilmiah yaitu logis, sistimatis, dinamis dan terstruktur. Perencanaan adalah fase proses keperawatan yang penuh pertimbangan dan sistematis dan mencakup pembuatan keputusan dan penyelesaian masalah. Perencanaan keperawatan bagian dari proses keperawatan. Perencanaan keperawatan yang dipersiapkan dengan baik tentu akan memberikan pengaruh yang baik terhadap pelaksanaan tindakan yang dilakukan.
\end{abstract}

Kata kunci: Asuhan Keperawatan, Perencanaan Keperawatan 


\section{LATAR BELAKANG}

Rumah sakit merupakan sebuah organisasi kesehatan yang sangat bermanfaat guna memberikan pelayanan kesehatan bagi masyarakat, sebagaimana tertera dalam UU RI No 44 pasal 1 (2009, p.2). Setiap tenaga kesehatan yang bekerja dirumah sakit harus bekerja sesuai dengan standar profesi, standar pelayanan rumah sakit, standar prosedur operasional yang berlaku, etika profesi, menghormati hak pasien, dan mengutamakan keselamatan pasien. Tenaga kesehatan tersebut diantaranya tenaga medis dan penunjang medis, tenaga keperawatan, tenaga kefarmasian, tenaga manajemen rumah sakit dan tenaga non kesehatan UU RI No 44 pasal 12-13 (2009, p.11-12). Salah satu pelayanan kesehatan yang diberikan oleh tenaga kesehatan adalah pelayanan keperawatan, Sebagai bagian dari pelayanan kesehatan, maka pelayanan keperawatan yang dilakukan oleh tenaga perawat memiliki tugas diataranya memberikan asuhan keperawatan (Hidayat, 2011, p.75).

Asuhan keperawatan yang dilakukan oleh tenaga perawat bersifat rutin dan sekitar $30 \%$ pelaksanaan asuhan keperawatan menggunakan pendekatan proses keperawatan.
Standar asuhan yang tercantum dalam Standar Praktik Klinis Keperawatan terdiri dari lima fase asuhan keperawatan:

1) Pengkajian; 2) Diagnosa;

3) Perencanaan; 4) Implementasi; dan

5) Evaluasi.

Salah satu manfaat dari penerapan asuhan keperawatan yang baik adalah meningkatkan mutu dan kualitas pelayanan dalam bidang keperawatan (Kozier, 2010).

Perencanaan adalah fase proses keperawatan yang penuh pertimbangan dan sistematis dan mencakup pembuatan keputusan dan penyelesaian masalah. Tujuan dari pengkajian mengenai intervensi keperawatan sasaran utamanya adalah perawat. Dengan mengetahui pentingnya dari intervensi/perencanaan keperawatan, perawat akan sadar dan mampu meningkatkan penegetahuan dalam menyusun atau menetapkan perencanaan yang akan diaplikasikan oleh klien di rumah sakit. Kajian ini menggunakan metode kualitatif, metode kualitatif ini bersifat memberikan penjelasan dengan membuat analisis. Hasil yang diharapkan dari kajian ini adalah untuk memberikan informasi mengenai intervensi keperawatan berdasarkan NIC, agar perawat memiliki pengetahuan luas dalam membuat perencanaan asuhan keperawatan yang tepat untuk meningkatkan kesehatan klien di rawat jalan maupun rawat inap di rumah sakit. 


\section{METODE}

Kajian ini menggunakan metode kualitatif, metode ini bersifat memberikan penjelasan dengan membuat analisis. Proses pengkajian ini lebih menggunakan landasan teori dengan mengumpulkan data, bereksplorasi bebas yang telah disimpulkan dari berbagai sumber-sumber, yaitu buku, majalah, koran, jurnal print maupun jurnal online bertema perencanaan keperawatan. Saya membaca dari berbagai referensi berupa buku, jurnal print maupun jurnal online. Melalui metode ini saya memahami dan mengidentikasi perencanaan keperawatan, bagaimana membuat prioritas masalah, membuat tujuan dan kriteria hasil, memutuskan perencanan keperawatan yang akan diimplementasikan.

\section{HASIL}

Berdasarkan hasil, bahwa perawat yang professional dalam memberikan asuhan tentu akan mempersiapkan terlebih dahulu perencanaan yang akan diimplementasikan. Semua tindakan pelayanan dilakukan berdasarkan proses keperawatan.

Model Asuhan Keperawatan Profesional adalah sebagai suatu sistem (struktur, proses dan nilai- nilai) yang memungkinkan perawat profesional mengatur pemberian asuhan keperawatan termasuk lingkungan untuk menopang pemberian asuhan tersebut (Hoffart \& Woods, 1996 dalam Hamid, 2001).

Pengetahuan dan motivasi perawat juga berpengaruh, salah satu literature saya menunjukkan bahwa perawat yang memiliki pengetahuan yang tinggi mengenai proses keperawatan termasuk intervensi keperawatan akan dapat memberikan pelayanan yang semakin baik kepada pasien.

Semakin tinggi pengetahuan perawat maka akan semakin baik pula perawat menerapkan perencanaan yang telah dipersiapkan. Ini menunjukkan pengetahuan yang dimiliki perawat menentukan ketepatan perawat dalam memberikan pelayanan.

Mutu pelayanan keperawatan sebagai indikator kualitas pelayanan kesehatan menjadi salah satu faktor penentu citra institusi pelayanan kesehatan dimata masyarakat.

Mutu pelayanan kesehatan menurut Azwar, adalah yang menunjuk pada tingkat kesempurnaan pelayanan kesehatan, yang disatu pihak dapat menimbulkan kepuasan pada setiap pasien sesuai dengan tingkat kepuasan rata-rata penduduk, serta dipihak lain tata cara penyelenggaraannya sesuai dengan kode etik dan standar pelayanan professional yang telah ditetapkan. 
Perencanaan adalah fase proses keperawatan yang penuh pertimbangan dan sistematis dan mencakup pembuatan keputusan dan penyelesaian masalah. Dalam perencanaan, perawat merujuk pada data pengkajian klien dan pernyataan diagnosis sebagai petunjuk dalam merumuskan tujuan klien dan merancang intervensi keperawatan yang diperukan untuk mencegah, mengurangi, atau menghilangkan masalah kesehatan klien. Intervensi keperawatan adalah setiap tindakan, berdasarkan penilaian klinis dan pengetahuan, yang perawat lakukan untuk meningkatkan hasil pada klien (McCloskey \& Bulechek, 2000).

\section{PEMBAHASAN}

Menurut Nursing Interventions Classification (NIC) (2013), intervensi keperawatan merupakan suatu perawatan yang dilakukan perawat berdasarkan penilaian klinis dan pengetahuan perawat untuk meningkatkan outcoem pasien/klien.

Intervensi keperawatan adalah panduan untuk perilaku spesifik yang diharapkan dari klien, dan atau/atau tindakan yang harus dilakukan oleh perawat. Intervensi dilakukan untuk membantuk klien mencapai hasil yang diharapkan (Deswani, 2009).

Banyak para ahli menulis pengertian perencanaan keperawatan, antara lain sebagai berikut:
1. Hunt Jennifer dan Mak

Rencana asuhan keperawatan adalah catatan yang ada tentang intervensi rencana keperawatan.

2. Mayer

Rencana asuhan keperawatan adalah pengkajian yang sistematis dan identifikasi masalah, penentuan tujuan, dan identifikasi masalah, penentuan tujuan, dan pelaksanaan serta cara-cara atau strategi.

3. Lu Verne Wolff, RN, dkk (1998)

Rencana asuhan keperawatan adalah tindakan yang dilakukan ketika memberi asuhan keperawatan kepada seseorang.

4. Pusdiklat Depkes (DJJ Keperawatan, 1997)

Perencanaan keperawatan yang akan dilakukan untuk menanggulangi masalah sesuai dengan diagnosis keperawatan yang telah ditentukan dengan tujuan terpenuhinya kebutuhan klien.

5. Lismidar H., SKM (1989)

Perencanaan keperawatan adalah mennetukan prioritas, menulis tujuan, dan merencanakan tindakan keperawatan.

6. Zaidin Ali, SKM, MBA, MM (1989)

Perencanaan keperawatan adalah suatu rangkaian kegiatan penentuan langkah-langkah pemecahan 


masalah dan prioritasnya,
perumusan tujuan, $\begin{array}{lr}\text { rencana } \\ \text { tindakan, dan penilaian } & \text { asuhan } \\ \text { keperawatan pada } & \text { klien } \\ \text { berdasarkan analisis data dan } & \\ \text { diagnosis keperawatan. } & \end{array}$

Tujuan dilakukannya perencanaan asuhan keperawatan adalah sebagai berikut:

1. Meningkatkan komunikasi antara pemberi asuhan keperawatan.

2. Memberikan asuhan secara langsung dan didokumentasikan.

3. Catatan dapat digunakan untuk evaluasi, penelitian, dan aspek legal.

4. Sebagai dokumentasi bukti untuk layanan asuransi.

Beberapa langkah dalam merumuskan perencanaan keperawatan sebagai berikut:

\section{Menentukan Prioritas Masalah}

Penetapan prioritas adalah penyusunan urutan diagnosis keperawatan/masalah klien dengan menggunakan tingkat kepentingan untuk memperoleh tahapan intervensi keperawatan yang dibutuhkan (Hendry dan Walker, 2004).

Berdasarkan kepentingannya, prioritas dapat dikategorikan sebagai berikut:

a. Prioritas Tinggi :situasi yang mengancam kehidupan (nyawa seseorang) sehingga perlu dilakukan tindakan terlebih dahulu.

b. Prioritas Sedang :situasi yang tidak gawat dan tidak mengancam kehidupan klien.

c. Prioritas Rendah :situasi yang tidak berhubungan langsung dengan prognosis dari suatu penyakit yang secara spesifik.

2. Menuliskan Kriteria Evaluasi (Hasil) / (Outcomes)

Tujuan klien dan tujuan keperawatan adalah standar atau ukuran yang digunakan untuk mengevaluasi kemajuan klien atau keterampilan perawat. Tujuan klien seperti halnya semua komponen proses perencanaan asuhan bersifat dinamis. Oleh karena itu, tujuan pasien dapat berubah dengan cepat. Pernyataan tujuan pasien yang spesifik dan indivisual merupakan hal yang penting digunakan untuk mengevaluasi respon pasien terhadap perawatan dan mengevaluasi keberhasilan rencana tindakan.

a. Tujuan klien

Tujuan klien merupakan pernyataan yang menjelaskan suatu perilaku klien, keluarga atau kelompok yang dapat diukur setelah intervensi keperawatan diberikan.

b. Tujuan keperawatan

Tujuan keperawatan digunakan sebagai petunjuk untuk memilih 
intervensi keperawatan dan kriteria dalam evaluasi intervensi keperawatan.

3. Memilih rencana atau intervensi keperawatan

Tipe intervensi :

a. Intervensi perawat

Respon perawat terhadap kebutuhan perawatan kesehatan dan diagnosa keperawatan klien. Intervensi ini tidak membutuhkan supervisi atau arahan orang lain, instruksi dokter atau profesi lainnya. Intervensi mencakup aktivitas kehidupan sehari- hari (ADL), penyuluhan kesehatan, promosi kesehatan dan konseling.

b. Intervensi Dokter

Respon dokter terhadap diagnosa medis dan perawat menyelesaikan instruksi tertulis dokter. Intervensi tidak selalu berada dalam praktik legal keperawatan tetapi intervensi tersebut berada dalam praktik keperawatan, bagi perawat untuk menyelesaikan instruksi tersebut.

c. Intervensi Kolaboratif Terapi yang membutuhkan pengetahuan, keterampilan dan keahlian khusus dari berbagai profesional keperwatan kesehatan. Terapi yang juga membutuhkan kerjasama antara dua profesi.

4. Dokumentasi Rencana Tindakan Petunjuk penulisan rencana tindakan keperawatan yang efektif :

a. Sebelum menuliskan rencana tindakan keperawatan, kaji ulang semua data yang ada sumber data yang memuaskan.

b. Daftar dan jenis masalah aktual, resiko dan kemungkinan. Berikan prioritas utama pada masalah aktual yang mengancam jiwa, yang dihubungkan dengan masalah yang mengancam kesehatan.

c. Untuk mempermudah agar bisa dimenegerti dalam membuat rencana tindakan berilah gambaran dan ilustarasi digunakan untuk perawatan klien atau ketika menggambarkan lokasi anatomi.

d. Tuliskan dengan jelas, khusus, terukur, kriteria hasil yang diharapkan untuk menetapkan masalah.

e. Selalu ditanda tangani dan diberi tanggal rencana tindakan, hal ini penting karena seorang perawat profesional akan bertanggung jawab dan tanggung gugat untuk melaksanakan rencana tindakan yang telah tertulis. 
f. Tuliskan rasional dari rencana tindakan.

g. Klien dan keluarganya jika memungkinkan diikut sertakan dalam perencanaan.

h. Rencana tindakan harus sesuai dengan waktu yang ditentukan dan diusahakan untuk selalu diperbaharui.

\section{PENUTUP}

Perencanaan keperawatan menjadi dasar perawat dalam mengimplementasikan tindakan yang akan dilakukan. Beberapa hal yang perlu diperhatikan dalam perenacanan keperawatan seperti menentukan prioritas masalah, menentukan tujuan dan kriteria hasil yang diharapkan, merumuskan rencana tindakan keperawatan dan rasional rencana tindakan keperawatan. Perencanaan keperawatan merupakan bagian dari proses keperawatan yang bermanfaat dalam pelayanan dan asuhan yang akan diberikan perawat kepada pasien. 


\section{DAFTAR PUSTAKA}

1. Agustin, Ratna. (2017).

Optimalisasi Pelaksanaan

Discharge Planning Melalui

Pengembangan Model Discharge

Planning Terintegrasi Pelayanan

Keperawatan: Jurnal Keperawatan

Muhammadiyah. Vol: 2 (1).

2. Budiono. (2016). Konsep Dasar

Keperawatan. Jakarta: Pusdik

SDM Kesehatan.

3. Budiono, \& Parman, S. (2015).

Konsep Dasar Keperawatan.

Jakarta: Bumi Medika.

4. Budiono, \& Pertami, S.B. (2016).

Konsep Dasar Keperawatan.

Jakarta: Bumi Medika.

5. Bulechek, M.G dkk. (2013).

Nursing Interventions

Classification (NIC), 6th

Indonesian edition. Indonesia:

Mocomedia.

6. Butar-Butar, J., \& Simamora, R. H.

(2016). Hubungan Mutu Pelayanan

Keperawatan dengan Tingkat

Kepuasan Pasien Rawat Inap di

RSUD Pandan Kabupaten Tapanuli

Tengah. Jurnal

Ners

Indonesia, 6(1), 51.

7. Dermawan, Deden. (2012). Proses Keperawatan; Penerapan Konsep \& Kerangka Kerja. Yogyakarta: Gosyen Publising.
8. Moorhead Sue, dkk. (2013).

Nursing Outcomes Classification

(NOC), 5th Indonesian edition.

Indonesia: Mocomedia.

9. Nurhidayah. (2014). Manajemen Model Asuhan Keperawatan Profesional Tim dalam Peningkatan Kepuasan Pasien di RS. Jurnal Kesehatan UIN Alauddin Makassar. Vol: 7(2). Hal: 410-411.

10. Rosdahl, B. C. \& Kowalski, T. M. (2014). Buku Ajar Keperawatan Dasar. Ed.10.Vol 1. Jakarta: EGC.

11. Wirdah, Husnul \& Yusuf, Muhammad. (2016). Penerapan Asuhan Keperawatan Oleh Perawat Pelaksana di Rumah Sakit Banda Aceh. Banda Aceh: Universitas Syah Kuala. 